\title{
Why Preservice Teacher Empowerment with Five Dimension Matters in Language Pedagogy Context
}

\author{
${ }^{1}$ Universitas Pendidikan Indonesia, Bandung, Indonesia \\ Universitas Swadaya Gunung Jati, Cirebon, Indonesia \\ ${ }^{2}$ Universitas Pendidikan Indonesia, Bandung, Indonesia \\ *Corresponding author. Email: Maisa22230@upi.edu
}

Maisa $^{1, *}$, Didi Suherdi ${ }^{2}$, Bachrudin Musthafa ${ }^{2}$

\begin{abstract}
Why Preservice teacher Empowerment matters in teaching language at teacher education program. Nevertheless, the conservative teaching practices often have the effect of disempowering students. The process of Student empowerment is the iterative process, which engages five integrated dimension such as knowledge dimension, learning dimension, skill and competence dimension, personal growth dimension, and the classroom community dimension. The aim of the paper is to figure out the preservice teachers, teacher educator, and mentor teacher' belief on why preservice teacher empowerment with five dimensions matters in teacher education program especially English Education. The research method is a case study which elaborates questionnaire, interviews, and document analysis to collect the data. The analysis found that the description knowledge dimension: types of knowledge that preservice teacher should have; learning dimension: learning interest, motivation, habit, and commitment; competence dimension: critical thinking, communication, collaboration, and creativity; personal growth dimension: selfawareness, self-control, self-direction, self-reflection; classroom community dimension: connectedness, group norm, group rule, and reward systems. The implication of the findings relates to the process of preservice teacher empowerment that leads to sustainability of teacher education programs.
\end{abstract}

Keywords: Competence, classroom community, learning, knowledge, personal growth

\section{INTRODUCTION}

Empowerment has long been a crucial concept in disciplines such as critical pedagogy, liberation, freedom, psychology, multicultural, social work, and transformative education. Within each perspective, empowerment is central to the work of humanizing human lives, which encompass a sense of personal control to link clearly to greater health and well-being (Cattaneo, \& Chapman, 2010; Sue, 1978; Zimmerman, 1995).

Empirical evidence from recent research provides that empowerment is a key component of transformative value, as higher education is an on-going process of transformation of students (Cheng, 2016; Murray, 2019). In this study, the pre-service teacher empowerment is related to the five major dimension: knowledge, learning, personal growth, competence, and communal classroom.

\subsection{The Five Dimensions of Preservice Teacher Empowerment}

The relevant issues and terms of the empowerments are its definition and development for decades, the components of empowerment, the dimension of student empowerment, the conception of learning, the conception of knowledge, the self-efficacy and personal growth as personal development, the competence, and the social action and community.

\subsubsection{Dimension of Knowledge}

Frymier, Shulman, and Houser (1996) with his colleagues in Stanford University launched a research program on" Knowledge Growth in Teaching" in which they studied the knowledge development of novice secondary teachers in English, Science, Mathematics, and Social Studies in the year of teacher preparation and the first year of their teaching. As the result of their study, Randall (1997), Shulman postulated seven 
knowledge bases which are important for teachers. They are as follows: (1) Content Knowledge or the subject knowledge in this case is English lesson. (2) General Pedagogy (3) Curriculum knowledge, which refers to the knowledge about the materials used by the teachers and educational system. (4) Pedagogical-content knowledge which encompasses the way how the target language presented and learnt, the methodology, approaches, and techniques of teaching English. (5) knowledge of learners' characteristics. (6) Knowledge of Education context (7). Knowledge of educational ends, values, philosophy, and history.

\subsubsection{Dimension of Learning}

Cheng (2016) proposes that effective learning is not only a process for students to acknowledge and to examine the overlaps and tensions between existing and new ideas but also is related to learning interest, learning motivation, learning habits, and learning commitment.

\subsubsection{Learning Interest}

According to Johann Friedrich Herbart, one of the early pioneers of modern psychology, interest is closely related to learning. Dewey (1913) develops the idea of interest by distinguishing between interest-oriented learning and learning that neglects a student's interest.

\subsubsection{Learning Motivation}

Like interest, motivation is another crucial factor of effective leaning. As Cole, Field, and Haris (2004) recommended, motivation is "the willingness to attend and learn the material in a development program," so student motivation could significantly affect their level of effort expended on a learning activity.

\subsubsection{Learning Habit}

Habit is becoming the centre of the learning process. "Habits arise from context-response learning which is acquired slowly with experience" (Cheng, 2016), and A student maintains habit through learning.

\subsubsection{Learning Commitment}

Commitment is another vital construct of a successful student learning experience. Commitment reflects a desire, and it is based on personal choice rather than a legal obligation (Cheng, 2016).

\subsubsection{Dimension of Competence}

Merriam-Webster Dictionary defines competence as the quality or state of being competent such as quality or state of having sufficient knowledge, judgment, ski, or strength. McClelland (1974) defines competency as "an underlying characteristic of an individual that is causally related to criterion-referenced effective and/or superior performance in a job or situation. The term "underlying characteristics" is chosen to indicate that competencies are ways of thinking or behaving which generalize across situations and endure for a reasonably long period of time. Spencer (1993) suggested six competencies: achievement and action. Impact and influence, cognitive, helping, and human service, managerial, and personal effectiveness.

\subsubsection{Dimension of Personal Growth}

Scholar describing empowerment often include the individual's sense of agency- the individual's belief about his or her abilities that Riger (1993) set apart from the individual's actual power. For example, in the social sphere, Gutierrez (1991) describes part of empowerment as an increase in "personal power" or "experiencing oneself as the powerful or capable person" (p. 202). Kroeker (1995) declared that the psychological goals of empowerment are to increase feelings of value, selfefficacy, and control. Fitzsimons and Fuller (2002) suggested that the empowerment approach promotes recognition of power and capabilities that individuals already possess. Intrapersonal empowerment (Zimmerman, 1995) is a broad conceptual umbrella in Zimmerman's network, including overlapping concepts such as self-awareness, self-control, self-efficacy, selfdirection, and self-reflection.

\subsubsection{Dimension of Communal Classroom}

A classroom community is built when students come together as a class member to work toward the common goal of learning. (Dörnyei, 2009). It helps students feel valued and connected to the teacher and the other students in the class. There are some benefits of fostering classroom community: (1) fill students' needs for belonging, (2) provide a way for all students to engage to the classroom activities, (3) Teach students social skills such as collaboration, and sense of responsibility towards others. To make classroom community runs well, there some strategies that support such as group norms, group rule, group responsibility, connectedness, and reward system.

\section{METHOD}

The research design is a case study which its result cannot be generalised because it has in dept data analysis (Alwasilah, 2015; Hamied, 2017). The aim of the study is to figure out the belief of the preservice teachers, the teacher educators, the preservice teacher, and the mentor teacher about the why the preservice teacher empowerment with five dimensions matters in the English Teaching Education Program. The research questions are what they belief on knowledge, learning, competence, personal growth, and classroom 
community dimensions. The setting of the research is the English Education Program in Teacher Education Faculty Universitas Swadaya Gunung Jati. The participants are four preservice teachers and teacher educators of English Education Program. The design of the research is a case study. The data were collected for three semesters with three different courses at English Education Program include Instructional Design, English Material Development, and Teaching Practicum. The class observation did during the courses a year before the teaching practicum. The dept interview was conducted during the personal coach at the two different courses and the teaching practicum. Meanwhile the questionnaire in the form of learning and teaching reflection were taken at the end of the courses and the end of the week at the teaching practicum. The data from document and questionnaire are used to analyse the knowledge dimension and learning dimension. The data from dept interview and classroom observation are used to analyse the competence dimension, personal growth dimension, and classroom community dimension.

\section{FINDINGS AND DISCUSSION}

The findings of research are classified into five dimensions of preservice teacher empowerment. The personal growth dimension is the only one which focuses on what the preservice teachers believe about the personal growth and learning which could empower themselves and how they empower personal growth and learning dimension with each other. Meanwhile the dimensions of knowledge, competence, and the communal classroom have different perspectives from other participants including teacher educator and mentor teacher' belief on the preservice teacher empowerment process.

\subsection{Dimension of Knowledge}

The dimension of knowledge is the essential dimension of process of the preservice teacher empowerment. As suggested by Shulman (1986), dimension of knowledge of the teachers are including the content knowledge, the pedagogy knowledge, the technology knowledge and the technology content knowledge. Those are also including declarative knowledge and procedure knowledge (Bhavnani \& Bates, 2002). The process of preservice teacher in dimension of knowledge is indicated when they could construct declarative knowledge (what to do) and procedure knowledge, (how to do it). As TE \#1 states:

"If we as the teacher educator would make the preservice teachers powerful, so we have to let them construct what to know and how to do it. By providing class activities with encourage them to explore their own interest and their creativity to accomplish their own target." (TE\#1)

The process of the preservice teacher constructs the knowledge by deciding what they learn and how to do it is the representative of the declarative knowledge and procedural knowledge. Once the preservice teachers could construct the declarative knowledge (what to learn) and procedural knowledge (how to do it) they could find themselves powerful. As it has been stated by PST1:

"At the beginning of the lecture, I always set my interest and target of knowledge from the subject and I also set how to get my target at the process to the end of the lecturer. When I get confused on finding the strategy to do my project, I always discuss with my friends and my lecturer. Then I could get into the right path on my own target again. "PST\#1

By giving the space of learning such as classroom discussion and personal coach session, the preservice teachers are encouraged to find their solution to the problem with their friends or the lecturer.

Mishra \& Kohler (2006) suggested that the teacher candidates must also master the technology content knowledge and the technology pedagogy knowledge. The teachers must know what technology knowledge and how to teach technology pedagogy knowledge (how to do it). As the TE\#2 stated:

"The learning condition of the Pandemic has forced teachers to learn and use some familiar LMS and how to teach using LMS." TE\#2

The statement is indicated as the technology knowledge and the technology pedagogy content knowledge ((Bhavnani \& Bates, 2002; Mishra \& Koehler, 2006). To empower he preservice teachers as the future teachers, need to construct the knowledge of technology and pedagogy content. Becoming the future teachers are more challenging to face the rapid changing world and the meet the demands of the future students and society.

The preservice teachers who have a good knowledge comprehension on content knowledge (Four language skill subjects), the pedagogy knowledge (Teaching and Learning Strategies, teaching four language skills), the technology pedagogy and content knowledge (Teaching media) have empowered themselves to perform their teaching practice during the classroom. (Ashcroft, 1987; Freire, 2018; Mishra \& Kohler, 2002; Murray, 2019; Shulman, 1986). The better the preservice teachers construct their knowledge dimension; they could empower themselves during the classroom activities and teaching practicum. 


\subsection{Dimension of Learning}

The effective learning is not only a process for students to acknowledge and to examine the overlaps and tensions between existing and new ideas but also is related to learning interest, learning motivation, learning habits, and learning commitment (Cheng, 2016). The Learning dimension is the essential dimension in preservice teacher empowerment. The learning process which occurs during the education program for more than three years before the teaching practicum encourage them to recognize their learning interest, learning motivation, learning habit, and learning commitment. As it is stated by TE\#1:

"Most students who take the English Education program, have good interest in learning English better. However, there are some students who take the English program because their parents support." (INT TE\#1).

Although some preservice teachers' learning interest do not come from their own choice, they started to love.

"My parents and my sister suggested me to take the English Education Program, and Now I love English and want to be English teachers like my sister and my lecturer." (PST\#1)

The phenomena is in line with the concept of learning interest which emerges the idea of interest and points out that interest leads students to develop a motivational orientation, which determines the learning outcome, including the level of comprehension, use of learning strategies, and quality of the emotional experience. Interest in this sense is described as "content-specific motivational characteristic composed of intrinsic feeling-related and value-related valences" (Cheng, 2016; Schiefele, 1991).

Like the learning interest, learning motivation is the willingness to attend and learn the material in a development program, so student motivation could significantly affect their level of effort expended on a learning activity. Both preservice teachers and Teacher Educators suggested that the strategies of delivering materials become the critical point which could encourage the learning motivation or discourage it. As they stated:

"I sometime starting my first meeting course by giving them questionnaires to see my students background knowledge about my course and to know their expectation what to learn and how to do it during the course" (TE)

By giving the preservice teachers pre-questionnaires, the teacher educator is trying to encourage their students' willingness to attend and learn the material in the courses. And it is in line with what the students' opinion:
"I feel better and confident when I've already known what I want to learn and what my lecturer wants me to do at the end of the course. I started to choose my interest and move to the class project based on the lecturer's guidance." (QPST3)

The student belief is in line with the current theories which stated that the learning motivation is related someone feeling confidence to gain the success. The higher the desire to succeed, the stronger willing to attempt a complex task (Cheng, 2016). Cultivating student learning motivation is very crucial to highlight students to approach education with a range of motivations due to a variety of factors, such as age and previous experiences, and response

Regarding to the learning habit which mainly influenced by the daily activities of the preservice teachers. two of them are the private English teachers meanwhile the others are the one who are active in the organization inside and outside the campus.

"I also believe that when I teach my private students at the same time, I learn something. It is beyond the English Materials. Sometimes it is more about emotional practice. Again, I learn when I teach. That is my way creating my learning habit." (INTPST1)

The preservice teachers' experience shows that it is in line with the learning habit statement by Cheng (2016) which declares that a desirable habit would guarantee the fertile ground for skills to develop, so knowing student learning habits would provide clues to help them form desirable habits. One example is that of the student who learns strategically for grades, so tier desirable habits may differ from those who are genuinely keen to learn, as the latter would employ more personal effort or self-regulation in learning. $\mathrm{Yu}$ (2011) reveals that high-performing students engage more often in reading ahead, doing the homework, and participating in class than low-performing students. Reading resources and materials, daily revision, and personal notetaking could, therefore, be desirable habits for students to achieve effective learning. Academics and universities could constantly reinforce and develop these good habits in order for them to become habitual for students.

Unlike the learning habit, the learning commitment is more about the students' personal learning dimension which takes on different forms, such as commitment to goals, time, and plans, and it is related to students personal characteristics, expectations, motivations ad academic goals. Due to the phenomena, PST1 and PST who have experience in teaching private class then they have good commitment in learning to achieve the goal to become good English Teachers. PST3 and PST4 who love doing organization in campus that they believe could also maintain their learning commitment during the education program. 
"Since I have already experience becoming the English teacher which I also earn some money from it, I have a desire to achieve my goal and get the best at every subject so I could give good example to my private students and others." (INT.PST1)

The condition of the preservice teachers shows how the build their learning commitment which focus on achieving their final goal to graduate with the best grade and become a professional English teacher in the future which is in line with definition of learning commitment which reflects a desire, and it is based on personal choice rather than a legal obligation (Cheng, 2016; Tellefsen \& Thomas, 2005). Students' commitment could be influenced largely by their self-regulation towards academic goals.

To conclude the learning dimension becomes the vital process on preservice teachers' empowerment. (Cheng, 2016; Freire, 2018). The preservice teachers who have been able to show their interest in any courses and they have good motivation in getting and doing their best-in-class project by building the manageable learning habit and great learning commitment, they could empower themselves to get the better learning result and better teaching performance during the practicum.

\subsection{Dimension of Competence}

The Competence is one of the core elements concepts of the process of empowerment. The current competence which the preservice teachers should have are critical thinking, communication, collaboration, and creativity. Due to the issues, all participants have different arguments related to the practice of the competences.

\subsubsection{Critical thinking and communication}

Related to this competence, here are the opinion from the teacher educator which do the classroom observation for two different courses for one academic year:

"PST1 and PST4 have curiosity during the personal coach/discussion related their project. Meanwhile, PST2 and PST 3 are open to accept and revise their work based on the teacher educator suggestion to make their task better," (IN.TE)

\subsubsection{Communication}

Due to the communication competence, almost participant believe that the most important competence for the English Teacher candidate are the four language skills (listening, speaking, reading, and writing) are the essential skills to consider during the subject course Instructional design and Material development course, the teaching practicum as well. While teaching them for the one academic year which mainly have personal coach on doing the class project, the teacher educators argued that:

\subsubsection{Collaboration and Creativity}

Related to this current competence, almost participants believe that to meet the demand of the rapid changing world, the preservice teachers need to have this competence to collaborate with other experts and researchers to solve the problem and find the solution and innovation to make a better education transformation. As Teacher Educator have notice to the preservice teachers. He declares that:

"PST3 and PST4 shows to be active to do collaboration their group of work such as leading their friends to get the idea based on the job description given and made a creative video of English tutorial and publish then at YouTube. And PS1 and PST2 are active to clarify their idea to the group to make sure that the group are on the track with the job description of the class project of designing English materials creatively" (INT\#TE)

To conclude the competence dimension, the process of preservice empowerment cannot be separated from the emerging of competence dimension. (Ashcroft, 1987; Duhon-Haynes, 1996). Preservice teachers who could emerge their competence in doing critical thinking, be able to communicate with oral and written and collaborate well with their friends and their teacher educators and mentor teachers would be able to create innovation during the process of studying and the teaching practicum as well.

\subsection{Dimension of Personal Growth}

Due to this dimension, the mentor teacher has some arguments related to how the preservice teachers develop their personality during the teaching practicum observation.

\subsubsection{Self-Awareness and Self-control}

Related to these issues. The mentor teacher argues that PST1 has shown that having self-awareness during teaching awareness needs to be started by herself. She thinks that the problem she got must solved sooner to make everything better by doing consultation to the supervisor. Besides, she has shown that she could control her emotion when she got the problem to communicate with her mentor teacher. PST3 and PST4 are patient enough in facing the reality of their students which have limitation during the SFH. However, they could control the class and trying to get their students attention by giving the reward such as additional score to the students who gives responses quickly in the online class. 


\subsubsection{Self-Direction and Self-Reflection}

PST1 has prepared well the teaching materials for several meeting before she started teaching the classroom. PST3 has created materials for the students in more than one platform to be more accessible by his students then he could prepare the next job, making quizzes and articles. PST4 makes a detail plan about what he does and how he does it during the teaching practicum. PST1 and PST3 do the teaching reflection form every week and they could make a better plan to solve the problem facing during the teaching practicum. PST4 is the one who seldom to do teaching reflection form but he does and help a lot his mentor teachers to do her job at schools. However, he could still have a better performance in delivering materials on his own channel during the practicum.

To conclude this dimension. The personal growth dimension becomes the long-life process which the preservice teachers must emerge beyond the teaching education program. (Ashcroft, 1986; Bandura, 2002; Freire, 2018; Kivunja, 2014) The more they practice emerging their personality would empower themselves. The ones who have a great self-awareness, self-control, self-efficacy, and self-reflection could lead them to do self-direction, they could empower themselves during the process of learning program and the teaching practicum.

\subsection{Dimension of Communal Classroom}

To make classroom community runs well, there some strategies that support such as group norms, group rule, group responsibility, connectedness, and reward system. Regarding to this issue, the data taken from the interviews and the online class observation during the teaching practicum. The teacher educator and the mentor teacher have their arguments:

"PST1, PST3 and PST2 have been able to make a group norm during the teaching practicum. They made it by consulting with the mentor teachers and the students in online classroom group." (INT.MT)

Almost participants made the simple rule in online classroom group discussion, they know that them. students do not always have internet connection to access the online learning. It is in line with the theory of dynamic group (Dörnyei, 2009) which stated that the teachers must be able to create the rule and norm to stay connected to the students.

Reward Systems. Almost participants have made attractive reward system for the students. They gave the additional score to the students who are active responding the teacher instruction in group. To conclude this part, classroom community is the one which could empower the preservice teachers during the education program and teaching practicum. The preservice teachers who could engage with the classroom norm, rule, and connectedness in the group, they would get empowered themselves by getting/ giving the rewards from or to the teacher educators, mentor teachers and the to the students. The good group norm snd rule would empower the preservice teachers to give impact to the society (Ashcroft, 1987; Dörnyei, 2009; Duhon-Haynes, 2006).

\section{CONCLUSION}

The process of preservice teacher empowerment with five dimensions are the one united and iterative process which could empower the preservice teachers to meet the demand of the rapid changing world. The better the preservice teachers' knowledge, the more powerful their performance in teaching. The more motivated the preservice teachers in learning, the better they feel empowered in developing their competence and personal growth during the teaching practicum.

\section{REFERENCES}

Alwasilah, A. C. (2010). Pokoknya studi kasus. pendekatan kualitatif. Bandung: Kiblat.

Ashcroft, L. (1987). Defusing “empowering”: The what and the why. Language Arts, 64(2), 145-155.

Bandura, A. (2002). Social Cognitive Theory in Cultural Context. Applied Psychology, 51(2), 269-290.

Bhavnani, S. K., \& Bates, M. J. (2002). Separating the knowledge layers: Cognitive analysis of search knowledge through hierarchical goal decompositions. Proceedings of the American Society for Information Science and Technology, 39(1), 204-213.

Cattaneo, L. B., \& Chapman, A. R. (2010). The process of empowerment: A model for use in research and practice. American Psychologist, 65(7), 646. .

Cheng, M. (2016). Student Empowerment and Transformative Quality. In M. Cheng (Ed.), Quality in higher education (pp. 11-23). Brill Sense. .

Cole, M. S., Field, H. S., \& Harris, S. G. (2004). Student learning motivation and psychological hardiness: Interactive effects on students' reactions to a management class. Academy of Management Learning and Education, 3(1), 64-85. https://doi.org/10.5465/amle.2004.12436819

Dewey, J. (1913). Interest and effort in education. Boston, MA: Houghton Mifflin Co.

Dörnyei, Z. (2009). The psychology of second language acquisition. Oxford: Oxford University Press. 
Duhon-Haynes, G. M. (1996, March). Student empowerment; definition, implication, and strategies for implementation. Paper presented at the Third World Symposium, Louisiana.

Freire, P. (2018). Pedagogy of the oppressed. Bloomsbury publishing USA.

Fitzsimons, S., \& Fuller, R. (2002). Empowerment and its implications for clinical practice in mental health: A review. Journal of Mental Health, 11(5), 481-499. https://doi.org/10.1080/09638230020023

Frymier, A. B., Shulman, G. M., \& Houser, M. (1996). The development of a learner empowerment measure. Communication Education, 45(3), 181199.

Gutierrez, L. (1991). Empowering women of color: A feminist model. In M. Bricker-Jenkins, N. R. Hooyman, \& N. Gottlieb (Eds.), Feminist social work practice in clinical settings (pp. 199 -214). Newbury Park, CA: Sage.

Hamied, F. A. (2017). Research methods: A guide for first-time researchers. Bandung: UPI PRESS.

Kivunja, C. (2014). do you want your students to be jobready with 21 st century skills? Change pedagogies: A pedagogical paradigm shift from Vygotskyian social constructivism to critical thinking, problem solving and Siemens' digital connectivism. International Journal of Higher Education, 3(3), 81-91. https://doi.org/10.5430/ijhe.v3n3p81

Kroeker, C. J. (1995). Individual, organizational, and societal empower-ment: A study of the processes in a Nicaraguan agricultural cooperative. American Journal of Community Psychology, 23(5), 749764. https://doi.org/10.1007/BF02506990

McClelland, D. C. (1974). "Testing for competence rather than for 'intelligence' ": Reply. American Psychologist, 29(1), https://doi.org/10.1037/h0038240

Mishra, P., \& Koehler, M. J. (2006). Technological pedagogical content knowledge: A framework for teacher knowledge. Teachers college record, 108(6), 1017-1054.

Murray, L. (2019). Student empowerment. In W. L. Filho (Ed.), Encyclopaedia of sustainability in higher education (pp. 1546-1577). Switzerland: Springer

Riger, S. (1993). What's wrong with empowerment. American Journal of Community Psychology, 21(3), 279-292.
Schiefele, U. (1991). Interest, learning, and motivation. Educational Psychologist, 26(3-4), 299-323.

Shulman, L. (1986). Those who understand knowledge growth in teaching. Education researchers, 15(2), 4-44. https://doi.org/10.3102/0013189x015002004

Spencer, S. M. (1993). Competence at work: Models for superior performance. John Willey \& Sons, Inc.

Sue, D. W. (1978). Eliminating cultural oppression in counselling: Toward a general theory. Journal of Counselling Psychology, 25(5), 419-428.

Tellefsen, T., \& Thomas, G. P. (2005). The antecedents and consequences of organizational and personal commitment in business service relationships. Industrial Marketing Management, 34(1), 23-37. https://doi.org/10.1016/j.indmarman.2004.07.001

Yu, D. D. (2011). How much do study habits, skills, and attitudes affect student performance in introductory college accounting courses? New Horizons in Education, 59(3), 1-15.

Zimmerman, M. A. (1995). Psychological empowerment: Issues and illustrations. American Journalof Community Psychology, 23, 581-599. https://doi.org/10.1007/bf02506983 